\title{
The combined effects of different fat replacers and rennet casein on the properties of reduced-fat processed cheese
}

\author{
Christopher N. Schädle, ${ }^{1,2 *}$ (1) Peter Eisner, ${ }^{2,3}$ and Stephanie Bader-Mittermaier ${ }^{2}$ () \\ ${ }^{1}$ Friedrich-Alexander University Erlangen-Nürnberg, Chair of Aroma and Smell Research, Emil Fischer Centre, \\ Department of Chemistry and Pharmacy, 91054 Erlangen, Germany \\ ${ }^{2}$ Fraunhofer Institute for Process Engineering and Packaging IVV, Department of Process Development for Plant Raw Materials \\ and Food Process Development, 85354 Freising, Germany \\ ${ }^{3}$ Technical University of Munich (TUM), TUM School of Life Sciences Weihenstephan, 85354 Freising, Germany
}

\section{ABSTRACT}

Reduced-fat food products can help to prevent obesity and other diet-related diseases. However, the removal of fat often impairs the sensory and textural properties of foods, leading to low consumer acceptance. In this study, we tested various concentrations of fat replacers (inulin, corn dextrin, polydextrose, and microparticulated whey protein) combined with rennet casein to investigate their effects on the melting behavior, dynamic rheological properties, and hardness of reduced-fat processed cheese. We found that increasing concentrations of inulin and corn dextrin reduced the flowability of cheese in the melting test and can thus be used to inhibit flow during heating. Microparticulated whey protein did not affect flowability but caused an increase in the storage and loss moduli as well as the temperature at gel-sol transition. A similar effect was also shown for rennet casein, whereas inulin and polydextrose had little or no effect on these rheological parameters. Corn dextrin had no effect on the storage and loss moduli, but affected the gel-sol transition temperature. No changes in hardness were detected for any concentration of the fat replacers, but increasing the rennet casein content also increased the hardness of the samples, regardless of the fat replacer used. Our results indicate the different concentrations and combinations of fat replacers and rennet casein that can be included in reduced-fat processed cheese to develop products with specific rheological properties, thus meeting future demand for reduced-fat products with attractive sensory attributes.

Key words: rheology, calorie reduction, hardness, flowability

Received October 2, 2019

Accepted December 29, 2019.

*Corresponding author: christopher.schaedle@ivv.fraunhofer.de

\section{INTRODUCTION}

The prevalence of high-energy foods combined with a sedentary lifestyle is one risk factor leading to obesity and adverse health-related dietary concerns, which are globally associated with high healthcare costs (Nielsen et al., 2002; WHO, 2016; Kent et al., 2017). Therefore, an urgent need exists for lower-calorie foods that retain the sensory and textural properties of high-energy foods. Consumers often dislike low-calorie products due to changes in their structural, textural, and organoleptic characteristics, leading to low consumer acceptance (Hamilton et al., 2000). Processed cheese comprises significant amounts of fat, with approximately $45 \mathrm{~g}$ of fat in DM being the major source of calories. Therefore, fat replacers that mimic the properties of fat are included as ingredients for calorie reduction.

An ideal fat replacer preserves lubrication and flow properties, possesses melting properties, enhances the ad- and absorption of food by taste receptors on the tongue, and improves the smoothness of reduced-fat food products (Jones, 1996). However, current commercial fat replacers do not possess all of these ideal properties at the same time, and optimal fat replacers or combinations thereof are thus required for each product on a case-by-case basis. Fat replacers may be based on fat, protein, or carbohydrate, each with specific properties and modes of action (O'Connor and O'Brien, 2011; Chavan et al., 2016).

Processed cheese is often used in high-energy foods such as burgers, offering a suitable model system for the investigation of fat reduction. Reduced-fat cheese has structural, functional, and sensory deficiencies compared with full-fat products (Mistry, 2001). The incorporation of fat replacers such as dietary fibers, hydrocolloids, and microparticulated proteins has been investigated in a wide range of dairy products in terms of the effects on rheological and sensory properties, as well as on microstructure (Desai and Nolting, 1995; 
Mackey and Desai, 1995; Johnson et al., 2009; Wadhwani and McMahon, 2012; Mohamed, 2015; Ferrão et al., 2016). Numerous replacement ingredients have also been investigated for their effects on the properties of processed cheese, including inulin (Sołowiej et al., 2015), pectin (Liu et al., 2008), gelatin, carrageenan, locust bean gum, guar gum (Swenson et al., 2000), konjac flour (Silva et al., 2016), and microparticulated whey protein (MWP) such as Simplesse (CP Kelco Germany, Grossenbrode, Germany) and Dairy-Lo (Pfizer Inc., Groton, CT; Muir et al., 1999; Tamime et al., 1999). Several reports indicate that inulin, polydextrose, and Simplesse are promising fat replacers for emulsion-based product systems (Srisuvor et al., 2013; Chung et al., 2014; Felisberto et al., 2015; Peng and Yao, 2017), hence their selection for this study, in addition to Nutriose (Roquette Frères, Lestrem, France). The corn dextrin product Nutriose has also been used as fat replacer (Lefranc-Millot et al., 2009; Martínez-Cervera et al., 2013), but no reports presently exist concerning its use in emulsion-based systems. The chemistry and techno-functional properties of the aforementioned fat replacers have been widely discussed (Mitchell, 1996; Singer, 1996; Franck and Bosscher, 2009; Lefranc-Millot et al., 2009; Stowell, 2009; Martínez-Cervera et al., 2013; Srisuvor et al., 2013; Karimi et al., 2015; Ipsen, 2017), as well as those of rennet casein in processed cheese (Guinee et al., 2004; Guinee, 2016).

Therefore, we investigated the effects of combinations of different fat replacers and rennet casein on the rheology, melting properties, and hardness of reducedfat processed cheese, to facilitate the development of reduced-fat processed cheese products with improved properties. We tested inulin, polydextrose, corn dextrin, and MWP as fat replacers at concentrations of 3 to $7 \mathrm{~g} / 100 \mathrm{~g}$. Given that the fat in processed cheese originates mainly from the cheese base, which contains rennet casein as protein and was reduced by means of the fat reduction, the highest concentration of each of the fat replacers $(7 \mathrm{~g} / 100 \mathrm{~g})$ was also combined with rennet casein at concentrations of 3 to $7 \mathrm{~g} / 100 \mathrm{~g}$ to determine the effects on reduced-fat processed cheese.

\section{MATERIALS AND METHODS}

\section{Materials}

In addition to deionized water, the following ingredients were used for the production of reduced-fat processed cheese samples: Edam cheese (DM content: 50.9\%; 30\% fat in DM, wt/wt; Molkerei Ammerland eG, Wiefelstede, Germany), sodium chloride (table salt), and lactose (pharmacopoeia quality) were purchased from a local supermarket. Matured Cheshire cheese (DM content: $67.9 \%$; $55 \%$ fat in DM, wt/wt), skim milk powder, trisodium citrate, and citric acid were kindly provided by Hochland Deutschland GmbH (Heimenkirch, Germany). The fat replacers used in this study were kindly donated by the suppliers: inulin (Orafti GR inulin, average degree of polymerization $\geq 10$, with $89 \%$ dietary fiber and maximum $8 \%$ sugar, from BENEO $\mathrm{GmbH}$, Mannheim, Germany), corn dextrin (Nutriose FM 06, partially acidic hydrolyzed corn starch having an average molecular weight of $5 \mathrm{kDa}$, representing 82 to $88 \%$ of dietary fiber, mono- and disaccharide content $0.3 \%$, and $<0.1 \%$ starch, from Roquette Frères), polydextrose (Litesse Ultra, with a maximum content of reducing sugar of $0.25 \%$ and a molecular weight below $22 \mathrm{kDa}$, from DANISCO Deutschland GmbH, Niebüll, Germany), MWP (Simplesse 100, having a protein content of $54 \%$ and a particle size of 0.01 to $3 \mu \mathrm{m}$, from CP Kelco Germany), and rennet casein (min. 50\% >90 mesh, minimum protein content of $78 \%$, from Lactoprot Deutschland GmbH, Kaltenkirchen, Germany).

\section{Manufacturing of Reduced-Fat Processed Cheese}

The basic formulation to prepare the reduced-fat processed cheese samples was $52 \mathrm{~g} / 100 \mathrm{~g}$ of cheese base (Edam and Cheshire), $24.6 \mathrm{~g} / 100 \mathrm{~g}$ of deionized water, $6 \mathrm{~g} / 100 \mathrm{~g}$ of skim milk powder, $2.7 \mathrm{~g} / 100 \mathrm{~g}$ of trisodium citrate, $0.3 \mathrm{~g} / 100 \mathrm{~g}$ of citric acid, and $0.3 \mathrm{~g} / 100 \mathrm{~g}$ of sodium chloride, as well as $14 \mathrm{~g} / 100 \mathrm{~g}$ of a combination of fat replacer, rennet casein, and lactose, as shown in Table 1. The fat replacers were MWP, corn dextrin, polydextrose, and inulin, which were used individually in the concentrations shown in Table 1 . The reducedfat processed cheese samples were produced in batch sizes of $800 \mathrm{~g}$ and in at least duplicate.

A Thermomix TM31 blender cooker (Vorwerk Elektrowerke GmbH and Co. KG, Wuppertal, Germany) with indirect heating was used to produce the reducedfat processed cheese samples at the laboratory scale. The cheese was grated into small pieces using a Haellde RG-250 cutting machine fitted with a 6 -mm grater (AB Haellde Maskiner, Kista, Sweden), weighed in portions, and stored at $-20^{\circ} \mathrm{C}$ to prevent further maturation during storage (Thomas et al., 1980). Before production of the reduced-fat processed cheeses, the grated cheese was defrosted at $4^{\circ} \mathrm{C}$ for approximately $5 \mathrm{~h}$ and then transferred to the cooker and minced for $30 \mathrm{~s}$ at speed level 5 (2,000 rpm). Pre-hydrated fat replacers (in 118 $\mathrm{g}$ of water) and a blend of skim milk powder, trisodium citrate, sodium chloride, citric acid, lactose, and the remaining water were added to the minced cheese and mixed for $1 \mathrm{~min}$ at speed level 2 (200 rpm). The tem- 
Table 1. Fat replacer content, rennet casein content, and the associated lactose content of the reduced-fat processed cheese recipes in the 2 series of experiments (FRS and RCS) and the protein content in DM of the samples with carbohydrate-based fat replacers (inulin, corn dextrin, polydextrose) and microparticulated whey protein (MWP)

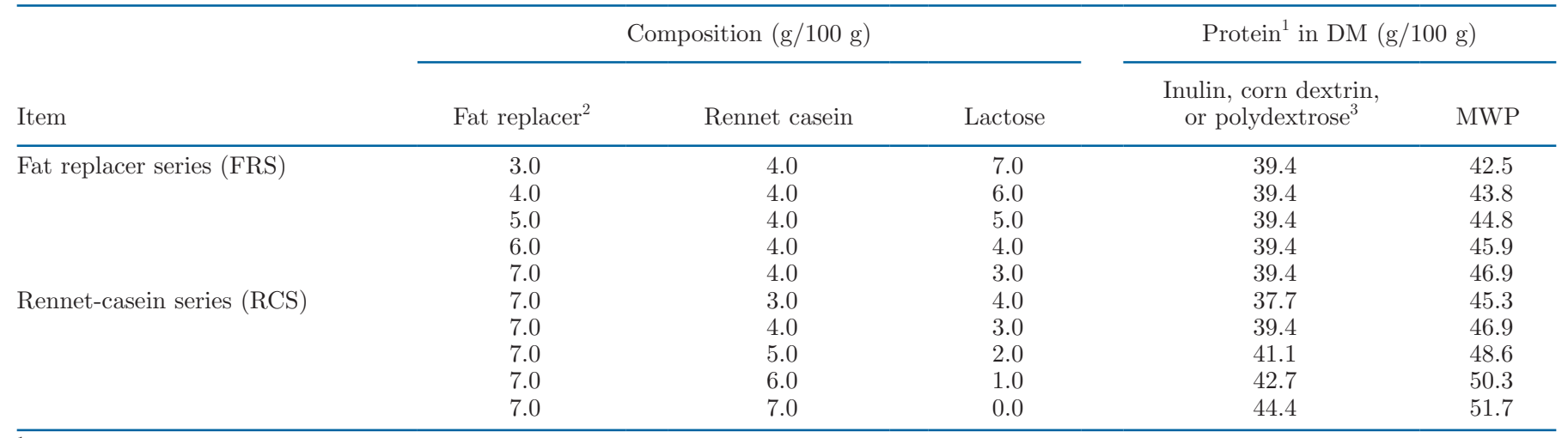

${ }^{1}$ Protein content was calculated using the protein contents of the raw materials.

${ }^{2}$ Inulin, corn dextrin, polydextrose, and MWP.

${ }^{3}$ Inulin, corn dextrin, and polydextrose contain no protein; thus, the protein content of the reduced-fat processed cheese samples is the same for all 3 of these fat replacers and independent of the concentration.

perature was set at $90^{\circ} \mathrm{C}$, and the mixture was heated for $7 \mathrm{~min}$ and constantly agitated at speed level 5 to achieve a final temperature of $86.8 \pm 1.5^{\circ} \mathrm{C}$. The $\mathrm{pH}$ was measured to maintain the target $\mathrm{pH}$ value of 5.6 using a 206-pH2 digital $\mathrm{pH}$ meter (Testo SE and Co. KGaA, Lenzkirch, Germany). The hot samples ( 120 $\mathrm{mL}$ ) were poured into stainless-steel molds (inner dimensions: $50 \times 9 \times 0.2 \mathrm{~cm}$ ) that had previously been covered with plastic sheets suitable for the storage of processed cheese. Another plastic sheet was placed over the cheese, and the hot mass was shaped using a rolling pin to prepare a processed cheese sheet with a thickness of $2 \mathrm{~mm}$. The samples were removed from the mold after a resting time of $10 \mathrm{~min}$ at room temperature, remained packed in plastic sheets, and were stored for 1 wk at $4 \pm 2^{\circ} \mathrm{C}$ before analyses.

To determine the effect of the fat replacer concentration ( 3 to $7 \mathrm{~g} / 100 \mathrm{~g}$ ), a constant proportion of rennet casein $(4 \mathrm{~g} / 100 \mathrm{~g})$ was used in the first set of experiments (fat replacer series, FRS). In the second set of experiments, a consistent amount of fat replacer (7 $\mathrm{g} / 100 \mathrm{~g}$ ) was tested with different concentrations of rennet casein in the range 3 to $7 \mathrm{~g} / 100 \mathrm{~g}$ (rennet-casein series, RCS). Lactose was included to maintain a constant DM content, and the required amount was calculated by summing the rennet casein and fat replacer content and making up the total to $14 \mathrm{~g} / 100 \mathrm{~g}$. The remaining ingredients and the processing conditions outlined above were the same for all formulations.

\section{Compositional Analysis}

The DM content of the reduced-fat processed cheese samples was determined according to AOAC (2005a) with a thermo-gravimetrical system at $105^{\circ} \mathrm{C}$ (TGA 601, Leco Corporation, St. Joseph, MI). The protein content of the raw materials (Edam and Cheshire) was calculated based on the nitrogen content, determined according to the Dumas combustion method as described by AOAC (2005b) using a Nitrogen Analyzer TruMac N (Leco Corporation) and a conversion factor of $\mathrm{N} \times 6.25$. The protein contents of the raw materials were used to calculate the final protein contents of the processed cheese samples. The fat content was determined based on the method of Caviezel, DGF C-III 19 (00) (DGF, 2018). In addition to this method, the fats were derivatized with trimethylsulfonium hydroxide before analyzing the derivatized fatty acids via gas chromatography. Protein and fat content were reported on a DM basis.

\section{Color Measurement}

The color of the reduced-fat processed cheese samples was measured using the DigiEye non-contact digital color imaging system (Digi Eye v. 2.62, VeriVide Ltd., Leicester, UK) according to the method of Böhner and Rieblinger (2016), using a white base as the background. The surface color was determined using CIE $\mathrm{L}^{*} \mathrm{a} * \mathrm{~b}^{*}$ values by measuring the average color of all pixels on the cheese sample surface. Three samples representing each produced recipe were measured, and the average values were calculated. The samples of each concentration series were compared with the sample with the lowest concentration of fat replacer (FRS) or rennet casein (RCS) as a reference by calculating the color difference $\quad \Delta E=\sqrt{\left(\Delta L^{*}\right)^{2}+\left(\Delta a^{*}\right)^{2}+\left(\Delta b^{*}\right)^{2}}, \quad$ where 
$\Delta L^{*}=L_{\text {Reference }}^{*}-L_{\text {Sample }}^{*}, \Delta a^{*}=a_{\text {Reference }}^{*}-a_{\text {Sample }}^{*}$, and $\Delta b^{*}=b_{\text {Reference }}^{*}-b_{\text {Sample }}^{*}$. The $L^{*}$ value represents lightness from black $(0)$ to white $(100)$, the $a^{*}$ value represents color ranging from red $(+)$ to green $(-)$, and the $b^{*}$ value represents color ranging from yellow $(+)$ to blue $(-)$.

\section{Melting Behavior}

The flowability of the reduced-fat processed cheese samples was determined using a modified Schreiber test, based on the method described by Altan et al. (2005). Cheese samples were cut into disks using a cork borer (35 mm diameter, $\sim 2.0 \mathrm{~mm}$ thick) and placed centrally on a glass petri dish $(10 \mathrm{~cm}$ diameter, $1.5 \mathrm{~cm}$ height). After covering with the lid, the samples were heated for $5 \mathrm{~min}$ at $232^{\circ} \mathrm{C}$ in an oven. The samples were then cooled for $30 \mathrm{~min}$ at room temperature. The area index (AIn) was measured using the computer-guided DigiEye system described before. The AIn was calculated using the following equation:

$$
\mathrm{AIn}=\frac{A_{E}-A_{0}}{A_{0}} \cdot 100 \%,
$$

where $A_{E}$ is the area of melted cheese and $A_{0}$ is the area of original unheated cheese. All measurements were taken 4 times for each sample batch.

\section{Rheological Properties}

The rheology of the cheese samples was measured using a Physica MCR 301 controlled shear strain rotational rheometer (Anton Paar Germany GmbH, Ostfildern, Germany), equipped with a serrated parallel plate geometry (PP25/P2, d $=25 \mathrm{~mm}$ ) to prevent slippage caused by melting fat. A Peltier heating system (H-PTD200) was used for accurate temperature control. Cheese samples were cut into disks using a cork borer $(25 \mathrm{~mm}$ diameter, $\sim 2.0 \mathrm{~mm}$ thick), placed in a sample box sealed with Parafilm M (Bemis Company Inc., Oshkosh, WI), and stored at $4^{\circ} \mathrm{C}$. The lower plate was tempered to $5^{\circ} \mathrm{C}$, and a layer of low-viscosity vegetable oil was applied to the exposed cheese surface to avoid desiccation during measurement (Sutheerawattananonda and Bastian, 1998). The normal force was kept constant at $1 \mathrm{~N}$ to ensure good contact, and a rest time of $5 \mathrm{~min}$ allowed any additional loading stresses to dissipate. During the measurement, the normal force was kept constant at $0.4 \mathrm{~N}$, and a minimal position of $0.8 \mathrm{~mm}$ was set for the gap. The measurements were conducted within the linear viscoelastic region, as determined by an amplitude sweep (constant angular velocity $\omega=10 \mathrm{rad} / \mathrm{s}$; varying deformation $\gamma=0.01$ to $100 \%$ ). To determine the temperature dependency, a temperature sweep was performed at a constant deformation of $\gamma=0.1 \%$ and a constant angular velocity of $\omega$ $=10 \mathrm{rad} / \mathrm{s}$, starting at $5^{\circ} \mathrm{C}$. The heating rate was $10^{\circ} \mathrm{C} /$ min between 5 and $45^{\circ} \mathrm{C}$, and $3^{\circ} \mathrm{C} / \mathrm{min}$ from 45 to $90^{\circ} \mathrm{C}$. Three measurements were carried out for each sample batch. The storage modulus $\left(\mathbf{G}^{\prime}\right)$, loss modulus $\left(\mathbf{G}^{\prime \prime}\right)$, and loss tangent $(\tan \delta$ ) were determined depending on temperature. The gel-sol transition temperature was determined as an indicator of meltability or, more precisely, the tendency toward structural weakening during heating (Guggisberg et al., 2007). At the gel-sol transition temperature, $\tan \delta=1$ and the curves of $\mathrm{G}^{\prime}$ and $G^{\prime \prime}$ intersect $\left(G^{\prime}=G^{\prime \prime}\right)$. This so-called crossover point can be used to identify the phase transition from solid-like to liquid-like behavior of the cheese during melting (Sutheerawattananonda and Bastian, 1998). At higher temperatures, $\mathrm{G}^{\prime \prime}$ becomes greater than $\mathrm{G}^{\prime}$, indicating a dominant viscous behavior. The maximum tan $\delta$ is considered a measure of flowability, more precisely the ability to flow at a certain temperature (Guinee et al., 1999; Schenkel et al., 2013; Hosseini-Parvar et al., 2015).

\section{Hardness}

The hardness of the reduced-fat processed cheese samples was analyzed using a TA-XTplus Texture Analyzer (Stable Micro Systems Ltd., Godalming, UK). Small disks of cheese were cut from the cheese sheets using a cork borer with a diameter of $25 \mathrm{~mm}$. Five disks were stacked to an approximate total height of 1 $\mathrm{cm}$, on the basis of the description in literature ( $\mathrm{Lu}$ et al., 2007; Trivedi et al., 2008), placed in a sample box sealed with Parafilm $\mathrm{M}$, and stored at $5^{\circ} \mathrm{C}$. The stack was compressed to a deformation of $50 \%$ using a $\mathrm{P} / 75$ 75-mm diameter probe (Stable Micro Systems Ltd.). The pre-test, test, and post-test speeds were $1 \mathrm{~mm} / \mathrm{s}$, and the trigger force was $5 \mathrm{~g}$. The samples were evaluated for hardness using Texture Exponent software (v. 6.1.10.0, Stable Micro Systems Ltd.). Hardness is defined as the force necessary to achieve a given deformation (Szczesniak, 1963). At least 5 measurements were carried out for each sample batch.

\section{Statistical Analysis}

The Shapiro-Wilk test was used to confirm Gaussian distribution, and the Levene test was applied to test for homogeneity of variance. The data were subsequently processed by a single-factor (univariate) ANOVA fol- 
lowed by Tukey's honest significance test $(\alpha=0.05)$. The data are expressed as mean \pm standard deviation.

\section{RESULTS AND DISCUSSION}

\section{Composition, $\mathrm{pH}$, and Color}

The DM content of all reduced-fat processed cheese samples was $50.5 \pm 0.1 \mathrm{~g} / 100 \mathrm{~g}$, because it was kept constant using lactose as inert filler. The fat content of all samples was $21.3 \pm 0.2 \mathrm{~g} / 100 \mathrm{~g}$ in DM and was thus more than $50 \%$ lower than comparable commercially available full-fat products with around $45 \mathrm{~g} / 100 \mathrm{~g}$ fat in DM. The calculated protein contents of the reduced-fat processed cheese samples are shown in Table 1. Because the carbohydrate-based fat replacers contained no protein, the protein content of these samples was independent of the fat replacer and their concentrations in the FRS. With MWP used as a fat replacer, the protein content increased with increasing MWP concentration. Calculating the energy densities of the samples, the values differ depending on the composition of each approach. The samples with $7 \mathrm{~g} / 100 \mathrm{~g}$ of polydextrose, 3 to $7 \mathrm{~g} / 100 \mathrm{~g}$ of rennet casein, and 0 to $4 \mathrm{~g} / 100 \mathrm{~g}$ of lactose had the lowest energy densities, around 858 $\mathrm{kJ} / 100 \mathrm{~g}(205 \mathrm{kcal} / 100 \mathrm{~g})$. The highest energy density, around $921 \mathrm{~kJ} / 100 \mathrm{~g}(220 \mathrm{kcal} / 100 \mathrm{~g})$, was found in the samples with $3 \mathrm{~g} / 100 \mathrm{~g}$ of corn dextrin, $4 \mathrm{~g} / 100 \mathrm{~g}$ of rennet casein, and $7 \mathrm{~g} / 100 \mathrm{~g}$ of lactose, mainly due to the high lactose content. Comparable commercially available full-fat processed cheeses have energy densities in the range of $1,344 \mathrm{~kJ} / 100 \mathrm{~g}(321 \mathrm{kcal} / 100 \mathrm{~g})$ to $1,461 \mathrm{~kJ} / 100 \mathrm{~g}(349 \mathrm{kcal} / 100 \mathrm{~g})$; thus we have reached a reduction range in energy density of around 30 to $40 \%$.

The $\mathrm{pH}$ of the reduced-fat processed cheese samples was $5.64 \pm 0.04$, as expected, and was not influenced by the fat replacers or by rennet casein. This meets the $\mathrm{pH}$ values of 5.4 to 5.8 required to produce a high-quality processed cheese (Kapoor and Metzger, 2008; Lucey et al., 2011; Hosseini-Parvar et al., 2015). Similarly, the addition of the selected fat replacers or rennet casein had no effect on the color of the final cheese samples, represented by $\mathrm{L}^{*}$ of $94.1 \pm 1.3, \mathrm{a}^{*}$ of $-3.0 \pm 0.7, \mathrm{~b}^{*}$ of $21.5 \pm 1.3$, and color difference $(\Delta \mathrm{E})$ of $<3$. No differences occurred, due to the white color of the fat replacers and their high solubility, which enables them to disperse uniformly in the cheese matrix. Because the color of cheese is a major determinant of consumer acceptance, it is important to ensure that the color of reduced-fat processed cheese is not affected by the fat replacers used. These results show that the fat replacement formulations do not affect the reduced-fat processed cheese color, and the processing conditions did not trigger non-enzymatic browning, which is possible in carbohydrate-based fat replacers due to Maillard reaction.

\section{Melting Behavior}

Flowability, represented by AIn, is one way to characterize the melting behavior of reduced-fat processed cheese. Our results show that the concentration of fat replacers affected $(P \leq 0.05)$ the flowability of the cheese samples (Figure 1A). Samples with inulin showed the highest AIn value of $145 \%$ at $3 \mathrm{~g} / 100 \mathrm{~g}$ in the FRS, representing a high ability to flow when heated. Further increases in FRS inulin concentration reduced $(P \leq 0.05)$ AIn to $87 \%$ at the concentration of $7 \mathrm{~g} / 100 \mathrm{~g}$. Furthermore, an increase in the FRS inulin concentration from 3 to $5 \mathrm{~g} / 100 \mathrm{~g}$ had a stronger effect on flowability than did an increase from 5 to $7 \mathrm{~g} / 100 \mathrm{~g}$, indicating a saturation effect. The lower flowability as the concentration of FRS inulin increases may reflect improved emulsion stability in the presence of inulin (Franck, 2002; Álvarez and Barbut, 2013). According to Guinee et al. (2004), the flowability of processed cheese is inversely correlated with the degree of emulsification. Furthermore, the gelling properties of inulin may reflect the uptake of free water (Hennelly et al., 2006) and the formation of a particle gel network under certain conditions, such as at higher concentrations and in response to the shearing applied during the manufacture of processed cheese (Franck and Bosscher, 2009). The gel network in the continuous phase of the cheese emulsion would be stabilized by adding higher concentrations of inulin. Thus, the higher the inulin content of a reduced-fat processed cheese, the higher the emulsion stability and gel formation tendency, leading to the observed reduction in flowability. In addition, Srisuvor et al. (2013) reported that inulin can form complexes with dairy protein aggregates via hydrogen bonds, becoming part of the structural network, as seen, for example, in yogurt. A related mechanism may, therefore, reduce flowability at higher inulin concentrations in reducedfat processed cheese samples. Similarly to FRS inulin, the AIn value of FRS corn dextrin decreased from $103 \%$ at $3 \mathrm{~g} / 100 \mathrm{~g}$ to $58 \%$ at $7 \mathrm{~g} / 100 \mathrm{~g}$, indicating that corn dextrin stabilizes the cheese emulsion as described for inulin and as will be described for whey protein. To the best of our knowledge, the emulsifying properties of $\mathrm{Nu}-$ triose corn dextrin and its ability to stabilize emulsions have not previously been reported. However, Nutriose has been used as wall material for encapsulation, which requires emulsifying properties and stability ( $\mathrm{Li}$ et al., 2016), providing evidence that it induces emulsification or stabilization or both during encapsulation. At higher concentrations, samples with FRS corn dextrin showed 
the lowest AIn compared with the other fat replacers, indicating a high capacity to reduce flowability at certain concentrations.

The flowability profile for cheese samples containing FRS polydextrose and FRS MWP differed from the samples containing FRS inulin and FRS corn dextrin. The AIn values of FRS polydextrose increased from $108 \%(3 \mathrm{~g} / 100 \mathrm{~g})$ to $134 \%(6 \mathrm{~g} / 100 \mathrm{~g})$ and then decreased $(P \leq 0.05)$ to $103 \%$ (7 g/100 g). Felisberto et al. (2015) reported low emulsion stability with polydextrose as a fat and starch substitute, which could explain the increase in flowability we observed at higher polydextrose concentrations, due to destabilization of the emulsion. At $7 \mathrm{~g} / 100 \mathrm{~g}$ FRS polydextrose, a potential saturation effect may have reduced the AIn. In cheese samples containing FRS MWP, the AIn value decreased $(P \leq$ 0.05 ) from $123 \%$ (3 g/100 g) to $95 \%$ ( $4 \mathrm{~g} / 100 \mathrm{~g})$, but a further increase in the FRS MWP concentration caused the AIn values to increase again to reach $107 \%$, which was not significantly different from the value observed at $3 \mathrm{~g} / 100 \mathrm{~g}$. Previously, MWP has been described as a non-interacting filler system (Desai and Nolting, 1995), which is inertly entrapped in the paracasein network, acting like milk fat as a lubrication enhancer by interrupting the cheese protein matrix and therefore weakening the paracasein network structure (Mackey and Desai, 1995; Schenkel et al., 2013; Ipsen, 2017). Because MWP does not melt as fat does under heating, it acts more like a ball bearing and thus enhances the flow of reduced-fat processed cheese (Schenkel et al., 2013). This contrasts with previous findings reported for the inclusion of non-denatured and denatured whey protein concentrates in reduced-fat processed cheese, because whey protein concentrates do not exhibit the same fat-like particle size and characteristics as MWP and thus the lubrication effect is likely to be absent. A higher whey protein concentrate content in reducedfat processed cheese is therefore generally associated with reduced flowability, due to emulsification (Rayan et al., 1980; Gupta and Reuter, 1993; Kaminarides and Stachtiaris, 2000; Mleko and Foegeding, 2000, 2001). Microparticulated whey protein can be considered as a combination of native proteins, and both soluble and insoluble protein aggregates are present. According to the literature, the microparticulated proteins generally have even better emulsion stabilization and texturing abilities than do the native proteins used to produce them (Sanchez and Paquin, 1997; Renard et al., 2002; Sun et al., 2015). Therefore, two superimposed effects described in the literature are anticipated for addition of MWP: reducing flowability due to the ability to stabilize emulsions, but also increasing flowability due to lubrication.

An increase in rennet casein concentration while maintaining a constant fat replacer content in the RCS did not significantly change the AIn values (Figure 1B), except for the samples containing $4 \mathrm{~g} / 100 \mathrm{~g}$ rennet casein combined with RCS inulin and RCS corn dextrin and $7 \mathrm{~g} / 100 \mathrm{~g}$ rennet casein combined with RCS polydextrose. In contrast to our findings, the flowability of processed cheese usually declines with increasing rennet casein concentration (Mleko and Foegeding, 2001; Guinee, 2011; Sołowiej et al., 2014; Guinee, 2016, 2017). In particular, the intact caseins


Figure 1. Area indices of reduced-fat processed cheese samples with different concentrations of fat replacers [inulin, corn dextrin, polydextrose, microparticulated whey protein (MWP)] in the fat-replacer series (FRS; A) and different rennet casein concentrations in the rennet-casein series (RCS; B), determined using the modified Schreiber test. Values are expressed as means \pm SD $(\mathrm{n}=8)$. a-c: Different lowercase letters indicate significant differences $(P \leq 0.05)$ between samples with different concentrations of the same fat replacer. A-C: Different capital letters indicate significant differences $(P \leq 0.05)$ between samples with different fat replacers at the same concentration level. 
predominantly found in young cheese and rennet casein are associated with lower flowability (Guinee, 2011, 2016). Additionally, rennet casein contains relatively high levels of calcium phosphate, which also produces cheeses with lower flowability (Sołowiej et al., 2014). In other cases, the hardness and poor melt properties of processed cheese have been associated with a higher degree of fat emulsification with increasing rennet casein concentration (Guinee, 2017) and the ability of rennet casein to stabilize emulsions (Guinee et al., 2004). Thus, the lower flowability of the reduced-fat processed cheese samples containing high concentrations of rennet casein was expected in our study, but we found that the flowability was unchanged or even slightly increased, perhaps reflecting differences in the formulations or in the production process. Furthermore, the relatively high concentration of $7 \mathrm{~g} / 100 \mathrm{~g}$ fat replacer in the RCS may have influenced the interaction of the rennet casein by disturbing and weakening the protein network. In addition, Mleko and Foegeding (2000) described the melting properties of the casein network under heating. Therefore, an overlap between the aforementioned effects may explain why the flowability of our samples did not change.

We found no differences among 3 of the fat replacers in the RCS (RCS inulin, RCS polydextrose, and RCS MWP). The combination of rennet casein with RCS corn dextrin showed the lowest AIn of all combinations over the whole concentration range. As stated earlier, corn dextrin also had the lowest AIn at high concentrations in the FRS, indicating that a high content of corn dextrin inhibited flowability of the reduced-fat processed cheese samples.

\section{Rheological Properties}

Dynamic rheological tests were used to characterize the viscoelastic properties of the reduced-fat processed cheese samples. The rheological measurements were conducted within the linear viscoelastic region of the samples as determined previously by amplitude sweeps, resulting in a shear strain of $\gamma=0.1 \%$ at an angular velocity of $\omega=10 \mathrm{rad} / \mathrm{s}$. The inner structure of the reduced-fat cheese samples during melting was evaluated by the storage $\left(\mathrm{G}^{\prime}\right)$ and loss $\left(\mathrm{G}^{\prime \prime}\right)$ moduli at the gel-sol transition temperature, determined by the temperature sweep (Figure 2). Protein-based ingredients (MWP, rennet casein) showed an increase $(P \leq 0.05)$ in $\mathrm{G}^{\prime}$ and $\mathrm{G}^{\prime \prime}$ at the gel-sol transition. For example, FRS MWP exhibited an increase from $4,045 \mathrm{~Pa}$ at $3 \mathrm{~g} / 100 \mathrm{~g}$ to $5,393 \mathrm{~Pa}$ at $7 \mathrm{~g} / 100 \mathrm{~g}$. The $\mathrm{G}^{\prime}$ and $\mathrm{G}^{\prime \prime}$ values for MWP samples were on average 1.5-fold higher than those of the other FRS and RCS samples. Rennet casein and MWP possess good emulsifying and emulsion stabiliz- ing properties (Guinee et al., 2004; Sun et al., 2015), suggesting that they reinforced the inner structure of the cheese samples at the gel-sol transition point. For MWP, this finding is in agreement with Ramel and Marangoni (2018a,b), who described a reinforcement of the matrix in processed cheese by inert particle fillers. At temperatures up to the gel-sol transition point, the emulsion stabilizing properties of MWP were probably more prevalent, and the ball bearing and structure weakening properties described previously appeared to take effect only at higher temperatures. Similarly, the cheese structure was enhanced at higher concentrations of rennet casein, matching the expectations for stabilizing the structure by adding intact casein and calcium. The casein network appeared to melt (Mleko and Foegeding, 2001) at temperatures above the gel-sol transition point. In addition, casein and fat replacers are likely to compete for water. The influence of moisture on the properties of cheese depends on both the available water content and the state of the water in the cheese matrix. In the recipe described herein, the DM content was kept constant in all samples by adjusting the amount of lactose, and the amount of added water was therefore equal in all formulations. A higher protein concentration is associated with a lower free water content (Hosseini-Parvar et al., 2015), which acts as a plasticizer in cheese (Marshall, 1990). Thus, in the presence of $7 \mathrm{~g} / 100 \mathrm{~g}$ fat replacer in the RCS, the effect of rennet casein on the available water content was another factor influencing the cheese structure and therefore the storage and loss moduli of the samples.

In contrast, for the carbohydrate-based fat replacers (inulin, corn dextrin, and polydextrose), the $\mathrm{G}^{\prime}$ and $\mathrm{G}^{\prime \prime}$ values were more or less equivalent $(\sim 3,300 \mathrm{~Pa})$ at the selected concentrations (Figure $2 \mathrm{~A}$ ). Furthermore, the 3 fat replacers acted similarly at equivalent levels in the concentration range of 3 to $6 \mathrm{~g} / 100 \mathrm{~g}$. Nonsignificant concentration-dependent differences were observed for $\mathrm{G}^{\prime}$ and $\mathrm{G}^{\prime \prime}$ in the concentration range 3 to $5 \mathrm{~g} / 100 \mathrm{~g}$ for all 3 of the fat replacers, but beyond these levels, the differences in $\mathrm{G}^{\prime}$ and $\mathrm{G}^{\prime \prime}$ were visible for inulin at $6 \mathrm{~g} / 100 \mathrm{~g}$ and $7 \mathrm{~g} / 100 \mathrm{~g}$, whereas for corn dextrin, the changes were seen only at a concentration of $7 \mathrm{~g} / 100$ g. As described previously, corn dextrin and inulin usually have lower emulsifying potentials than does rennet casein, so the addition of higher concentrations of these fat replacers affected $G^{\prime}$ and $G^{\prime \prime}$ to only a minor extent. Karimi et al. (2015) observed that inulin has a lower emulsifying potential than casein because the latter has many lipophilic sites that favor emulsification. Polydextrose had no significant effect on $G^{\prime}$ and $\mathrm{G}^{\prime \prime}$ at the gel-sol transition, possibly reflecting its poor emulsifying properties, which should be investigated in detail in a later study. Our results showed that increas- 

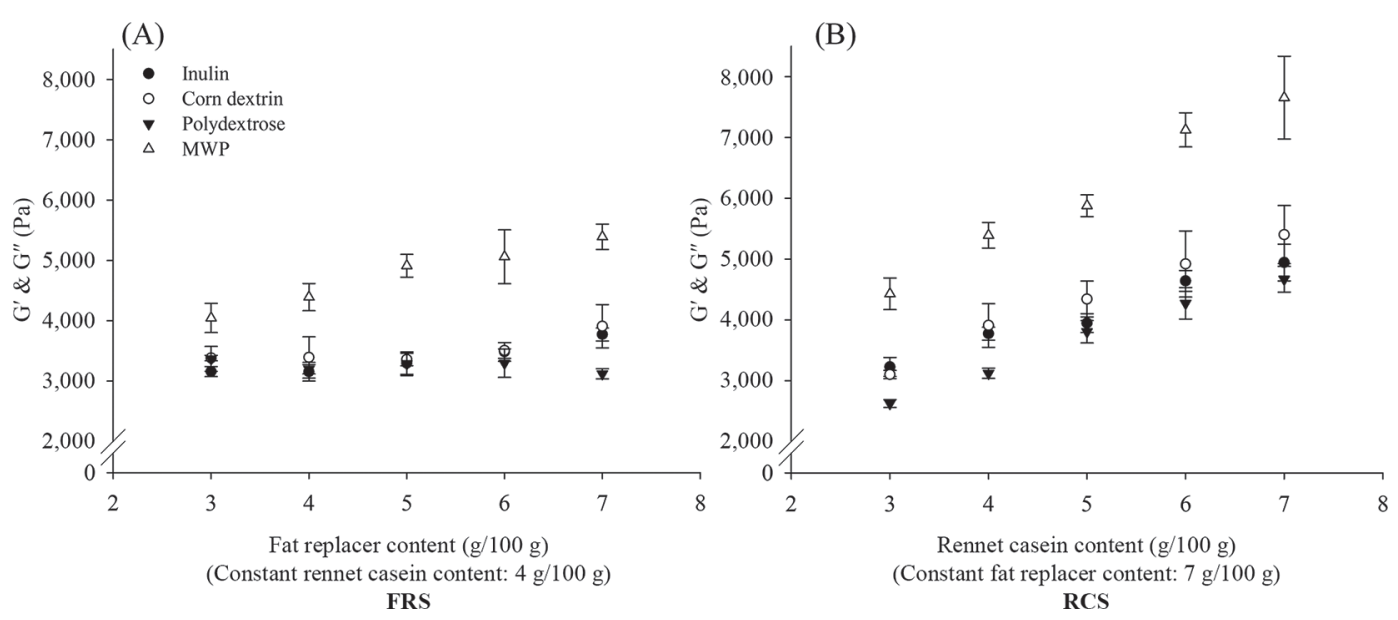

Figure 2. Changes in the storage and loss moduli $\left(\mathrm{G}^{\prime}\right.$ and $\left.\mathrm{G}^{\prime \prime}\right)$ of reduced-fat processed cheese with different concentrations of fat replacers [inulin, corn dextrin, polydextrose, microparticulated whey protein (MWP)] in the fat replacer series (FRS; A) and different rennet casein concentrations in the rennet-casein series (RCS; B) at the gel-sol transition temperature (where $\left.\mathrm{G}^{\prime}=\mathrm{G}^{\prime \prime}\right)$ during a temperature sweep $\left(5\right.$ to $90^{\circ} \mathrm{C}$ ) at an angular velocity of $10 \mathrm{rad} / \mathrm{s}$ and a constant deformation of $0.1 \%$. Values are expressed as means $\pm \mathrm{SD}(\mathrm{n}=6)$.

ing the polydextrose concentration from $3 \mathrm{~g} / 100 \mathrm{~g}$ to $7 \mathrm{~g} / 100 \mathrm{~g}$ had no obvious effect on the structure and viscoelastic properties of reduced-fat processed cheese. A fat replacer concentration of $7 \mathrm{~g} / 100 \mathrm{~g}$ was selected to study interactions between the protein or carbohydrate fat replacers and the rennet casein concentration in the RCS.

The gel-sol transition temperature is crucial for the examination of processed cheese structure, because the cheese starts to soften at this temperature, and therefore the gel-sol transition is a quality indicator for the meltability of cheese (Guggisberg et al., 2007). Figure 3 shows the gel-sol transition temperatures for the FRS and RCS samples. The concentrations of inulin and polydextrose in the FRS had no effect on the gelsol transition temperature $\left(48.5\right.$ to $48.7^{\circ} \mathrm{C}$ and 48.7 to $48.9^{\circ} \mathrm{C}$ ), which may reflect the similar cheese structures despite the higher concentration of fat replacers, as suggested by the unchanged $\mathrm{G}^{\prime}$ and $\mathrm{G}^{\prime \prime}$ values. Also, we found no differences between inulin and polydextrose at equivalent concentration levels over the whole range. In contrast, a gradual increase $(P \leq 0.05)$ in the gel-sol transition temperature was observed for corn dextrin at $6 \mathrm{~g} / 100 \mathrm{~g}\left(50.4^{\circ} \mathrm{C}\right)$ and $7 \mathrm{~g} / 100 \mathrm{~g}\left(52.3^{\circ} \mathrm{C}\right)$. However, because corn dextrin has not previously been used as a fat replacer in reduced-fat processed cheese, the effects cannot be explained fully, and further research is required. In the case of MWP, an increase $(P \leq 0.05)$ in the gel-sol transition temperature from 49.3 to $50.9^{\circ} \mathrm{C}$ was observed throughout the concentration range ( 3 to $7 \mathrm{~g} / 100 \mathrm{~g}$ ), but, even so, the total temperature increase was lower than that observed for corn dextrin and did not reduce the meltability of the reduced-fat processed cheese, in agreement with our flowability data. In con- trast, Schenkel et al. (2013) described a lower transition temperature with increased MWP concentration due to a structural weakening effect, probably due to small differences in the moisture content between the cheese samples with and without MWP, as well as to the fact that a higher moisture content reduces the gel-sol transition temperature (Hennelly et al., 2005). This effect was not observed in our study, in which the moisture content of the samples was carefully controlled.

In the RCS samples, we found concentration-dependent changes $(P \leq 0.05)$ in the gel-sol transition temperature (Figure 3B). An increase of approximately $2.0^{\circ} \mathrm{C}$ from 3 to $7 \mathrm{~g} / 100 \mathrm{~g}$ was observed for samples containing inulin, polydextrose, and MWP, whereas a gradual decline of 1.3 to $1.9^{\circ} \mathrm{C}$ from $3 \mathrm{~g} / 100 \mathrm{~g}$ to 5 to $7 \mathrm{~g} / 100 \mathrm{~g}$ rennet casein was observed for corn dextrin samples. Hosseini-Parvar et al. (2015) also found that the gel-sol transition temperature increases with increasing casein content, reflecting the enhanced casein-casein interactions that stabilize the cheese matrix. Rennet casein also contains calcium, which can form calcium bridges in the processed cheese samples during heating, contributing to a stabilized cheese matrix (Sołowiej et al., 2014). This may explain the higher $\mathrm{G}^{\prime}$ and $\mathrm{G}^{\prime \prime}$ moduli as well as the higher temperature at the gel-sol transition point as the rennet casein content increases in the reduced-fat processed cheese samples containing inulin, polydextrose, or MWP. Over the whole concentration range, the 2 fat replacers inulin and polydextrose were similar, but both were different $(P \leq 0.05)$ from the samples containing MWP. The gel-sol transition temperature profile with increasing rennet casein concentration in the presence of corn dextrin cannot be explained based on our current data 




FRS



Figure 3. Gel-sol transition temperature of reduced-fat processed cheese with different concentrations of fat replacers [inulin, corn dextrin, polydextrose, microparticulated whey protein (MWP)] in the fat replacer series (FRS; A) and different rennet casein concentrations in the rennet-casein series (RCS; B) as determined by a temperature sweep $\left(5\right.$ to $\left.90^{\circ} \mathrm{C}\right)$ at an angular velocity of $10 \mathrm{rad} / \mathrm{s}$ and a constant deformation of $0.1 \%$. Values are expressed as means $\pm \mathrm{SD}(\mathrm{n}=6)$. a-d: Different lowercase letters indicate significant differences $(P \leq 0.05)$ between samples with different concentrations of the same fat replacer. A-C: Different capital letters indicate significant differences $(P \leq 0.05)$ between samples with different fat replacers at the same concentration level.

and literature values, and further research is required to characterize this phenomenon in more detail.

In addition, the loss tangent $(\tan \delta)$ is related to cheese melting behavior and provides information about viscoelastic properties, because it is the quotient of the loss and storage moduli $\left(\mathrm{G}^{\prime \prime} / \mathrm{G}^{\prime}\right.$; Solowiej et al., 2014). Higher $\tan \delta$ values thus indicate a higher degree of flowability (Dimitreli and Thomareis, 2008). The maximum $\tan \delta$ values in a temperature sweep are used to predict the flowability of cheese (Mounsey and O'Riordan, 1999; Fox et al., 2017). The maximum tan $\delta$ values of the FRS and RCS samples are presented in Figure 4. The temperature at the maximum loss tangent was $78.0^{\circ} \mathrm{C} \pm 2.6^{\circ} \mathrm{C}$ for all samples. In FRS samples, increasing concentrations of inulin, corn dextrin, or polydextrose in the presence of $4 \mathrm{~g} / 100 \mathrm{~g}$ rennet casein did not affect $\tan \delta$. Similarly, in RCS samples, no differences were observed for $7 \mathrm{~g} / 100 \mathrm{~g}$ inulin and corn dextrin at increasing rennet casein concentrations of 3 to $7 \mathrm{~g} / 100 \mathrm{~g}$. However, RCS polydextrose showed an increase $(P \leq 0.05)$ in tan $\delta$ from 4.2 at $6 \mathrm{~g} / 100 \mathrm{~g}$ to 5.0 at $7 \mathrm{~g} / 100 \mathrm{~g}$ rennet casein.

The $\tan \delta$ values of FRS MWP decreased $(P \leq 0.05)$ from 4.5 to 3.3 with increasing concentrations of MWP ( 3 to $7 \mathrm{~g} / 100 \mathrm{~g}$ ) and from 3.7 to 2.8 at $7 \mathrm{~g} / 100 \mathrm{~g}$ RCS MWP with increasing concentrations of rennet casein (3 to $7 \mathrm{~g} / 100 \mathrm{~g}$ ). The RCS combinations with inulin and polydextrose showed the highest $\tan \delta$ value of 5.0 (at $7 \mathrm{~g} / 100 \mathrm{~g}$ rennet casein), whereas RCS MWP at 6 $\mathrm{g} / 100 \mathrm{~g}$ rennet casein exhibited the lowest $\tan \delta$ value of 2.7. Maximum $\tan \delta$ values in RCS were approxi- mately 1.4-fold higher for samples containing inulin and polydextrose compared with those containing corn dextrin and MWP. In FRS samples, the maximum tan $\delta$ values of polydextrose and inulin were approximately 1.2-fold higher than those of samples containing corn dextrin and MWP. The lower maximum $\tan \delta$ values of the reduced-fat processed cheeses containing MWP and corn dextrin indicated the tendency of these fat replacers to inhibit flowability. For corn dextrin, this was supported by the low AIn in the modified Schreiber test. The elastic properties of these samples were maintained to a greater extent during heating compared with samples containing inulin or polydextrose. Additionally, the samples containing polydextrose and inulin showed the lowest storage and loss moduli and temperatures at the gel-sol transition point, as well as low values for hardness, as described in the following section. These results indicated that polydextrose and inulin fat replacers might have little effect on the structure of the cheese.

\section{Hardness}

Texture analysis is extensively used to imitate the oral processing of food products and correlates with human sensory evaluations of these products (Marshall, 1990; Drake et al., 1999; Foegeding et al., 2003; Silva et al., 2012). Therefore, we investigated the influence of fat replacers and rennet casein on hardness in the reduced-fat processed cheese samples (Figure 5). The hardness values of FRS samples were mostly indepen- 
dent of the fat replacer concentration (Figure 5A). Similarly, Hennelly et al. (2006) found no differences in the hardness of imitation cheese containing different concentrations of inulin. The hardness of FRS polydextrose decreased $(P \leq 0.05)$ from $60.3 \mathrm{~N}$ at $3 \mathrm{~g} / 100 \mathrm{~g}$ to $50.8 \mathrm{~N}$ and $53.6 \mathrm{~N}$ at 6 and $7 \mathrm{~g} / 100 \mathrm{~g}$, respectively. Similarly, a decrease in hardness was observed for FRS corn dextrin samples upon increasing the concentration from $6 \mathrm{~g} / 100 \mathrm{~g}$ to $7 \mathrm{~g} / 100 \mathrm{~g}$. This slight loss of hardness at higher concentrations may reflect the disruption of the protein network as previously described for fat (Bryant et al., 1995; Gunasekaran and Ak, 2003). Another possibility is that corn dextrin had an adverse effect at concentrations higher than $6 \mathrm{~g} / 100 \mathrm{~g}$ due to increased interactions of the dextrin molecules, and, thus, a maximum inclusion level of $6 \mathrm{~g}$ per $100 \mathrm{~g}$ is anticipated. At low concentrations (3 to $5 \mathrm{~g} / 100 \mathrm{~g}$ ), FRS inulin samples showed the lowest hardness values $(49.3$ to $51.2 \mathrm{~N})$ among the 4 fat replacers $(P \leq 0.05)$, whereas MWP showed the highest $(82.1 \mathrm{~N}$ at $5 \mathrm{~g} / 100$ g). However, this value did not differ from the values obtained at other MWP concentrations. In our study, an increase in MWP concentration enhanced the inner structure in the rheological measurements as determined by $G^{\prime}$ and $G^{\prime \prime}$. However, the hardness did not increase with increasing MWP in our processed cheese samples. Thus, 2 opposing effects - namely, weakening of the protein network structure and the ability of MWP to stabilize emulsions - might have led to the observed results. Additionally, the high lactose content of MWP could influence the hardness of processed cheese
(Lieske and Konrad, 1994), given that a high lactose content is associated with lower hardness (Guinee et al., 2004; Macků et al., 2009; Guinee, 2017). Lactose was added to the cheese to maintain the DM content, because past studies have described the use of lactose as inert filler in reduced-fat processed cheese as the best compromise, despite its known weaknesses (Lenze et al., 2019). Furthermore, lactose becomes more soluble at higher temperatures (Nickerson and Moore, 1972) and thus has less influence at the higher temperatures used in the melting test and the temperature sweep. This could also explain the difference between the rheology at higher temperatures and the textural measurements, as discussed earlier. The storage modulus at $10^{\circ} \mathrm{C}$ (data not shown) correlated well with the hardness of the unmelted cheese samples, as previously described (Drake et al., 1999).

For RCS samples, regardless of the fat replacer type, the hardness showed a gradual increase with increasing rennet casein concentration (Figure 5B). The RCS MWP samples were the hardest at the given concentrations, and greater hardness was observed at rennet casein concentrations above $5 \mathrm{~g} / 100 \mathrm{~g}$. A similar pattern was observed for the other combinations of fat replacer and rennet casein. The increased hardness as a function of rennet casein concentration is supported by previous reports (Gunasekaran and Ak, 2003; Guinee, 2011; Sołowiej et al., 2014). Guinee $(2011,2016)$ attributed this greater hardness to a higher content of intact casein, which can be found in young cheese or in rennet casein. Rennet casein also contains calcium,
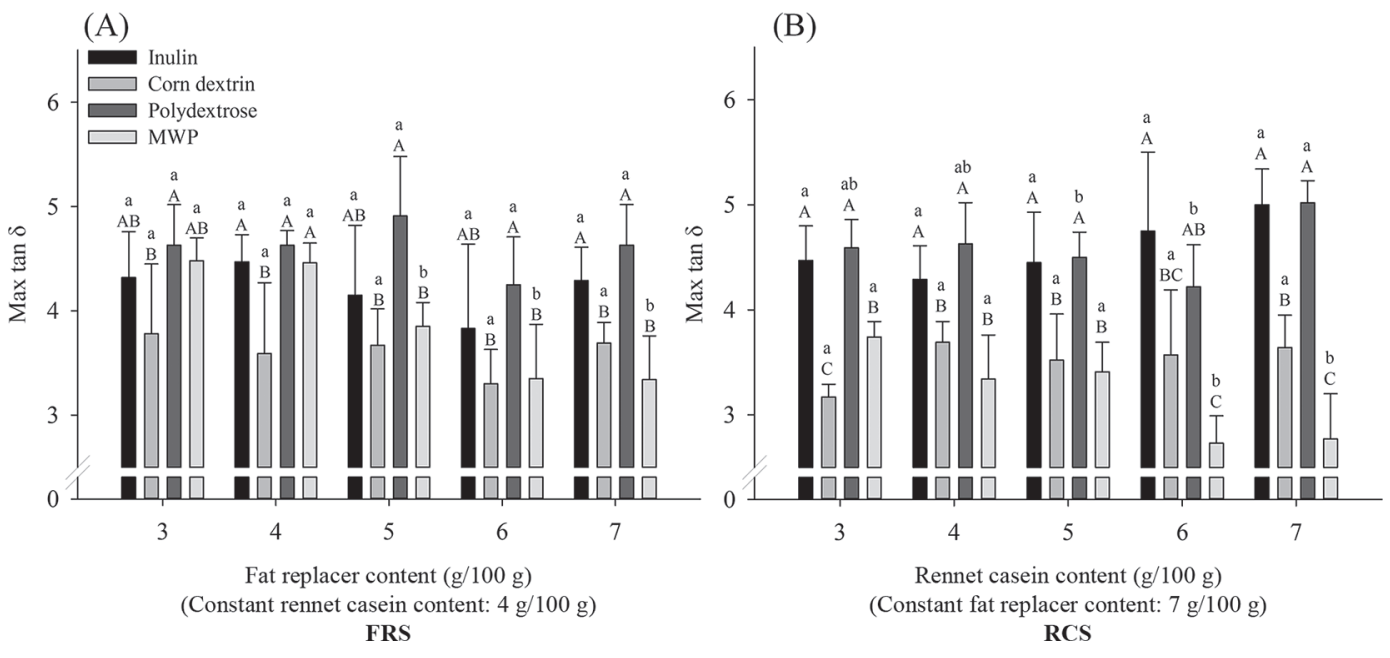

Figure 4. Maximum loss tangent (tan $\delta$ ) of reduced-fat processed cheese with different concentrations of fat replacers [inulin, corn dextrin, polydextrose, microparticulated whey protein (MWP)] in the fat replacer series (FRS; A) and different rennet casein concentrations in the rennet-casein series (RCS; B) as determined by a temperature sweep $\left(5\right.$ to $\left.90^{\circ} \mathrm{C}\right)$ at an angular velocity of $10 \mathrm{rad} / \mathrm{s}$ and a constant deformation of $0.1 \%$. Values are expressed as means $\pm \mathrm{SD}(\mathrm{n}=6)$. a,b: Different lowercase letters indicate significant differences $(P \leq 0.05)$ between samples with different concentrations of the same fat replacer. A-C: Different capital letters indicate significant differences $(P \leq 0.05)$ between samples with different fat replacers at the same concentration level. 



Figure 5. Hardness of reduced-fat processed cheese samples as a function of fat replacer [inulin, corn dextrin, polydextrose, microparticulated whey protein (MWP)] content in the fat replacer series (FRS) with constant rennet casein content (A) and of rennet casein content in the rennetcasein series (RCS) with a constant fat replacer concentration (B). Values are expressed as means \pm SD ( $\mathrm{n} \geq 10)$. a-d: Different lowercase letters indicate significant differences $(P \leq 0.05)$ between samples with different concentrations of the same fat replacer. A-C: Different capital letters indicate significant differences $(P \leq 0.05)$ between samples with different fat replacers at the same concentration level.

which could promote the formation of extended calcium bridges in the reduced-fat processed cheese samples during heating in the production process, increasing the hardness of the final products (Sołowiej et al., 2014; Guinee, 2016). Emulsifying salts can sequester calcium and are generally added during the production of processed cheese to improve the emulsification properties of casein by disrupting the calcium phosphate-protein network. Hydrophilic and lipophilic sections of the individual caseins are thus exposed, and the shear and heat cause the caseins to become hydrated by interacting with the aqueous and fat phases, emulsifying the cheese matrix (Gupta et al., 1984; Carić et al., 1985; Johnson et al., 2009). With a constant content of emulsifying salt in the formulation, the higher calcium content associated with the rennet casein content could exceed the calcium-sequestering capacity of the trisodium citrate. In addition to the higher casein content per se, this would lead to a harder texture in the final reduced-fat processed cheese samples (Guinee et al., 2004). Overall, rennet casein can be used to increase the hardness of processed cheese to meet the demands of specific applications.

Considering the slopes of the linear fits for the correlation of hardness and rennet casein concentration, no differences among the 4 RCS combinations were observed, indicating that regardless of the fat replacer, the change in concentration of the rennet casein had the same effect on the hardness of the reduced-fat processed cheese samples. On average, the hardness increased by approximately $18.5 \mathrm{~N}$ between 3 and $7 \mathrm{~g} / 100 \mathrm{~g}$ rennet casein. No differences in hardness were observed between the combinations with inulin and polydextrose for $3,4,5$, or $7 \mathrm{~g} / 100 \mathrm{~g}$ rennet casein or between the combinations with corn dextrin and polydextrose for 6 and $7 \mathrm{~g} / 100 \mathrm{~g}$ rennet casein.

\section{CONCLUSIONS}

We have investigated the effects of inulin, polydextrose, corn dextrin, MWP, and rennet casein on the color, flowability, rheology, and hardness of reduced-fat processed cheese samples. Appropriate combinations and concentrations of rennet casein and fat replacers can alter the rheological and textural properties of reduced-fat processed cheese to meet the requirements for specific applications and reduce calories by up to $40 \%$. The concentration of polydextrose had the lowest effect on the properties of the samples and is therefore preferable as a filler that can be used in different amounts. We found that higher concentrations of inulin or corn dextrin can be used to reduce flowability without affecting the properties of the unheated reduced-fat processed cheese samples. Our study provides the basis for further investigations in model systems to determine the effects of combinations of fat replacers on the inner structure and rheology of reduced-fat processed cheese.

\section{ACKNOWLEDGMENTS}

Preparation of this paper was supported by the enable Cluster and is cataloged by the enable Steering Committee as enable 022 (http://enable-cluster.de). This work was funded by a grant from the German 
Federal Ministry of Education and Research (BMBF; Bonn; grant number FK 01EA1409G). We also thank Maria Jacob and Ralf Polkowski (Hochland Deutschland GmbH, Heimenkirch, Germany) for their support and Lactoprot Deutschland GmbH (Kaltenkirchen, Germany) for providing the rennet casein. Thanks to Richard M. Twyman for proofreading the paper. The authors have not stated any conflicts of interest.

\section{REFERENCES}

Altan, A., M. Turhan, and S. Gunasekaran. 2005. Short communication: Comparison of covered and uncovered Schreiber test for cheese meltability evaluation. J. Dairy Sci. 88:857-861. https://doi .org/10.3168/jds.S0022-0302(05)72751-X.

Álvarez, D., and S. Barbut. 2013. Effect of inulin, $\beta$-glucan and their mixtures on emulsion stability, color and textural parameters of cooked meat batters. Meat Sci. 94:320-327. https://doi.org/10 $.1016 /$ j.meatsci.2013.02.011.

AOAC. 2005a. Method 925.10: Solids (total) and moisture in flour. In Official Methods of Analysis of the Association of Official Analytical Chemists (AOAC). G. W. Latimer and W. Horwitz, ed. AOAC, Gaithersburg, MD.

AOAC. 2005b. Method 968.06: Protein (crude) in animal feed. In Official Methods of Analysis of the Association of Official Analytical Chemists (AOAC). G. W. Latimer and W. Horwitz, ed. AOAC, Gaithersburg, MD.

Böhner, N., and K. Rieblinger. 2016. Impact of different visible light spectra on oxygen absorption and surface discoloration of bologna sausage. Meat Sci. 121:207-209. https://doi.org/10.1016/j.meatsci 2016.06.019.

Bryant, A., Z. Ustunol, and J. Steffe. 1995. Texture of Cheddar cheese as influenced by fat reduction. J. Food Sci. 60:1216-1219. https:// doi.org/10.1111/j.1365-2621.1995.tb04559.x.

Carić, M., M. Gantar, and M. Kalab. 1985. Effects of emulsifying agents on the microstructure and other characteristics of process cheese-A review. Food Structure 4:297-312.

Chavan, R. S., C. D. Khedkar, and S. Bhatt. 2016. Fat replacer. Pages 589-595 in Encyclopedia of Food and Health. B. Caballero, P. M. Finglas, and F. Toldrá, ed. Elsevier Academic Press, Cambridge, MA.

Chung, C., B. Degner, and D. J. McClements. 2014. Reduced calorie emulsion-based foods: Protein microparticles and dietary fiber as fat replacers. Food Res. Int. 64:664-676. https://doi.org/10.1016/ j.foodres.2014.07.034.

Desai, N., and J. Nolting. 1995. Microstructure studies of reduced-fat cheeses containing fat substitute. Pages 295-302 in Chemistry of Structure-Function Relationships in Cheese. E. L. Malin and M. H. Tunick, ed. Springer Verlag, Berlin, Germany.

DGF. 2018. Deutsche Einheitsmethoden: Zur Untersuchung von Fetten, Fettprodukten, Tensiden und verwandten Stoffen. 23. Aktualisierungslieferung zur 2. Aufl. Wissenschaftliche Verlagsgesellschaft, Stuttgart, Deutschland.

Dimitreli, G., and A. S. Thomareis. 2008. Effect of chemical composition on the linear viscoelastic properties of spreadable-type processed cheese. J. Food Eng. 84:368-374. https://doi.org/10.1016/j .jfoodeng.2007.05.030.

Drake, M. A., P. D. Gerard, V. D. Truong, and C. R. Daubert. 1999 Relationship between instrumental and sensory measurements of cheese texture. J. Texture Stud. 30:451-476. https://doi.org/10 .1111/j.1745-4603.1999.tb00230.x

Felisberto, M. H. F., M. T. E. L. Galvão, C. S. F. Picone, R. L. Cunha, and M. A. R. Pollonio. 2015. Effect of prebiotic ingredients on the rheological properties and microstructure of reduced-sodium and low-fat meat emulsions. Lebensm. Wiss. Technol. 60:148-155. https://doi.org/10.1016/j.lwt.2014.08.004.

Ferrão, L. L., E. B. Silva, H. L. A. Silva, R. Silva, N. Mollakhalili, D. Granato, M. Q. Freitas, M. C. Silva, R. S. L. Raices, M. C.
Padilha, P. B. Zacarchenco, M. I. M. J. Barbosa, A. M. Mortazavian, and A. G. Cruz. 2016. Strategies to develop healthier processed cheeses: Reduction of sodium and fat contents and use of prebiotics. Food Res. Int. 86:93-102. https://doi.org/10.1016/j .foodres.2016.04.034.

Foegeding, E. A., J. Brown, M. A. Drake, and C. R. Daubert. 2003. Sensory and mechanical aspects of cheese texture. Int. Dairy J. 13:585-591. https://doi.org/10.1016/S0958-6946(03)00094-3.

Fox, P. F., T. P. Guinee, T. M. Cogan, and P. L. H. McSweeney. 2017. Cheese: Structure, rheology and texture. Pages 475-532 in Fundamentals of Cheese Science. P. F. Fox, T. P. Guinee, T. M. Cogan, and P. L. H. McSweeney, ed. Springer, Boston, MA.

Franck, A. 2002. Technological functionality of inulin and oligofructose. Br. J. Nutr. 87(Suppl. 2):S287-S291. https://doi.org/10 $.1079 / \mathrm{BJN} / 2002550$

Franck, A., and D. Bosscher. 2009. Inulin. Pages 41-60 in Fiber Ingredients: Food Applications and Health Benefits. S. S. Cho and P. Samuel, ed. CRC Press, Boca Raton, FL.

Guggisberg, D., U. Bütikofer, and B. Albrecht. 2007. Melting and solidification characteristics of Swiss Raclette cheese measured by small amplitude oscillatory shear measurements. J. Texture Stud. 38:297-323. https://doi.org/10.1111/j.1745-4603.2007.00099.x.

Guinee, T. P. 2011. Pasteurized processed cheese products. Pages 805-813 in Encyclopedia of Dairy Sciences. J. W. Fuquay, P. F. Fox, and P. L. H. McSweeney, ed. Elsevier, Amsterdam, the Netherlands.

Guinee, T. P. 2016. Protein in cheese and cheese products: Structurefunction relationships. Pages 347-415 in Advanced Dairy Chemistry: Volume 1B: Proteins: Applied Aspects. P. L. H. McSweeney and J. A. O'Mahony, ed. Springer U.S., New York, NY.

Guinee, T. P. 2017. Pasteurized processed and imitation cheese products. Pages 1133-1184 in Cheese: Chemistry, Physics and Microbiology. 4th ed. P. L. H. McSweeney, P. F. Fox, P. D. Cotter, and D W. Everett, ed. Elsevier Academic Press, London, UK.

Guinee, T. P., M. A. E. Auty, and C. Mullins. 1999. Observations on the microstructure and heat-induced changes in the viscoelasticity of commercial cheeses. Aust. J. Dairy Technol. 54:84-89.

Guinee, T. P., M. Carić, and M. Kaláb. 2004. Pasteurized processed cheese and substitute/imitation cheese products. Pages 349-394 in Cheese: Chemistry, Physics, and Microbiology. Vol. 2. 3rd ed. P. F. Fox, ed. Elsevier, Amsterdam, the Netherlands.

Gunasekaran, S., and M. M. Ak. 2003. Cheese texture. Pages 299-329 in Cheese Rheology and Texture. S. Gunasekaran and M. M. Ak, ed. CRC Press, Boca Raton, FL.

Gupta, S. K., C. Karahadian, and R. C. Lindsay. 1984. Effect of emulsifier salts on textural and flavor properties of processed cheeses. J. Dairy Sci. 67:764-778. https://doi.org/10.3168/jds.S0022 -0302(84)81367-3.

Gupta, V. K., and H. Reuter. 1993. Firmness and melting quality of processed cheese foods with added whey protein concentrates. Lait 73:381-388. https://doi.org/10.1051/lait:1993435.

Hamilton, J., B. Knox, D. Hill, and H. Parr. 2000. Reduced fat products - Consumer perceptions and preferences. Br. Food J. 102:494506. https://doi.org/10.1108/00070700010336454.

Hennelly, P. J., P. G. Dunne, M. O'Sullivan, and E. D. O'Riordan. 2005. Increasing the moisture content of imitation cheese: Effects on texture, rheology and microstructure. Eur. Food Res. Technol. 220:415-420. https://doi.org/10.1007/s00217-004-1097-9.

Hennelly, P. J., P. G. Dunne, M. O'Sullivan, and E. D. O'Riordan. 2006. Textural, rheological and microstructural properties of imitation cheese containing inulin. J. Food Eng. 75:388-395. https:// doi.org/10.1016/j.jfoodeng.2005.04.023.

Hosseini-Parvar, S. H., L. Matia-Merino, and M. Golding. 2015. Effect of basil seed gum (BSG) on textural, rheological and microstructural properties of model processed cheese. Food Hydrocoll. 43:557-567. https://doi.org/10.1016/j.foodhyd.2014.07.015.

Ipsen, R. 2017. Microparticulated whey proteins for improving dairy product texture. Int. Dairy J. 67:73-79. https://doi.org/10.1016/ j.idairyj.2016.08.009.

Johnson, M. E., R. Kapoor, D. J. McMahon, D. R. McCoy, and R. G. Narasimmon. 2009. Reduction of sodium and fat levels in natural 
and processed cheeses: Scientific and technological aspects. Compr. Rev. Food Sci. Food Saf. 8:252-268. https://doi.org/10.1111/j .1541-4337.2009.00080.x.

Jones, S. A. 1996. Physical, chemical, and sensory aspects of fat replacement. Pages 59-86 in Handbook of Fat Replacers. S. Roller and S. A. Jones, ed. CRC Press, Boca Raton, FL.

Kaminarides, S., and S. Stachtiaris. 2000. Production of processed cheese using kasseri cheese and processed cheese analogues incorporating whey protein concentrate and soybean oil. Int. J. Dairy Technol. 53:69-74. https://doi.org/10.1111/j.1471-0307.2000 tb02661.x.

Kapoor, R., and L. E. Metzger. 2008. Process cheese: Scientific and technological aspects - A review. Compr. Rev. Food Sci. Food Saf. 7:194-214. https://doi.org/10.1111/j.1541-4337.2008.00040.x.

Karimi, R., M. H. Azizi, M. Ghasemlou, and M. Vaziri. 2015. Application of inulin in cheese as prebiotic, fat replacer and texturizer: A review. Carbohydr. Polym. 119:85-100. https://doi.org/10.1016/j .carbpol.2014.11.029.

Kent, S., F. Fusco, A. Gray, S. A. Jebb, B. J. Cairns, and B. Mihaylova. 2017. Body mass index and healthcare costs: A systematic literature review of individual participant data studies. Obes. Rev. 18:869-879. https://doi.org/10.1111/obr.12560.

Lefranc-Millot, C., D. Wils, J.-M. Roturier, C. Le Bihan, and M.-H. Saniez-Degrave. 2009. Nutriose soluble fiber. Pages 19-40 in S. S. Cho and P. Samuel, ed. Fiber Ingredients: Food Applications and Health Benefits. CRC Press, Boca Raton, FL.

Lenze, S., A. Wolfschoon-Pombo, K. Schrader, and U. Kulozik. 2019. Effect of the compositional factors and processing conditions on the creaming reaction during process cheese manufacturing. Food Bioproc. Tech. 12:575-586. https://doi.org/10.1007/s11947-019 -2234-6.

Li, X., N. Anton, and T. F. Vandamme. 2016. Spray-drying of nanoand microcapsules of nutraceuticals. Pages $455-478$ in Functional Food Ingredients and Nutraceuticals: Processing Technologies. J. Shi, ed. CRC Press, Boca Raton, FL.

Lieske, B., and G. Konrad. 1994. Microparticulation of whey protein: Related factors affecting the solubility. Z. Lebensm. Unters. Forsch. 199:289-293. https://doi.org/10.1007/BF01193314.

Liu, H., X. M. Xu, and S. D. Guo. 2008. Comparison of full-fat and low-fat cheese analogues with or without pectin gel through microstructure, texture, rheology, thermal and sensory analysis. Int. J. Food Sci. Technol. 43:1581-1592. https://doi.org/10.1111/j.1365 $-2621.2007 .01616 . x$

Lu, Y., N. Shirashoji, and J. A. Lucey. 2007. Rheological, textural and melting properties of commercial samples of some of the different types of pasteurized processed cheese. Int. J. Dairy Technol. 60:74-80. https://doi.org/10.1111/j.1471-0307.2007.00314.x.

Lucey, J. A., A. Maurer-Rothmann, and S. Kaliappan. 2011. Functionality of ingredients: Emulsifying salts. Pages 110-132 in Processed Cheese and Analogues. A. Y. Tamime, ed. Wiley-Blackwell, Ames, IA.

Mackey, K. L., and N. Desai. 1995. Rheology of reduced-fat cheese containing a fat substitute. Pages 21-26 in Chemistry of StructureFunction Relationships in Cheese. E. L. Malin and M. H. Tunick, ed. Springer Verlag, Berlin, Germany.

Macků. I., F. Buňka, B. Voldánová, and V. Pavlínek. 2009. Effect of addition of selected solid cosolutes on viscoelastic properties of model processed cheese containing pectin. Food Hydrocoll. 23:2078-2084. https://doi.org/10.1016/j.foodhyd.2009.03.020.

Marshall, R. J. 1990. Composition, structure, rheological properties, and sensory texture of processed cheese analogues. J. Sci. Food Agric. 50:237-252. https://doi.org/10.1002/jsfa.2740500211.

Martínez-Cervera, S., E. de la Hera, T. Sanz, M. Gómez, and A. Salvador. 2013. Effect of Nutriose on rheological, textural and sensorial characteristics of Spanish muffins. Food Bioproc. Tech. 6:19901999. https://doi.org/10.1007/s11947-012-0939-x.

Mistry, V. V. 2001. Low fat cheese technology. Int. Dairy J. 11:413422. https://doi.org/10.1016/S0958-6946(01)00077-2.

Mitchell, H. L. 1996. The role of the bulking agent polydextrose in fat replacement. Pages 230-244 in Handbook of Fat Replacers. S. Roller and S. A. Jones, ed. CRC Press, Boca Raton, FL.
Mleko, S., and E. A. Foegeding. 2000. Physical properties of rennet casein gels and processed cheese analogs containing whey proteins. Milchwissenschaft 55:513-516.

Mleko, S., and E. A. Foegeding. 2001. Incorporation of polymerized whey proteins into processed cheese analogs. Milchwissenschaft $56: 612-615$.

Mohamed, A. G. 2015. Low-fat cheese: A modern demand. International J. Dairy Sci. 10:249-265. https://doi.org/10.3923/ijds.2015 .249 .265 .

Mounsey, J. S., and E. D. O'Riordan. 1999. Empirical and dynamic rheological data correlation to characterize melt characteristics of imitation cheese. J. Food Sci. 64:701-703. https://doi.org/10 $.1111 /$ j.1365-2621.1999.tb15114.x.

Muir, D. D., A. Y. Tamime, M. E. Shenana, and A. H. Dawood. 1999. Processed cheese analogues incorporating fat-substitutes: 1. Composition, microbiological quality and flavour changes during storage at $5^{\circ} \mathrm{C}$. Lebensm. Wiss. Technol. 32:41-49. https://doi.org/10 $.1006 /$ fstl.1998.0509.

Nickerson, T. A., and E. E. Moore. 1972. Solubility interrelations of lactose and sucrose. J. Food Sci. 37:60-61. https://doi.org/10 .1111/j.1365-2621.1972.tb03385.x.

Nielsen, S. J., A. M. Siega-Riz, and B. M. Popkin. 2002. Trends in food locations and sources among adolescents and young adults. Prev. Med. 35:107-113. https://doi.org/10.1006/pmed.2002.1037.

O'Connor, T. P., and N. M. O'Brien. 2011. Butter and other milk fat products: Fat replacers. Pages 528-532 in Encyclopedia of Dairy Sciences. J. W. Fuquay, P. F. Fox, and P. L. H. McSweeney, ed. Elsevier, Amsterdam, the Netherlands.

Peng, X., and Y. Yao. 2017. Carbohydrates as fat replacers. Annu. Rev. Food Sci. Technol. 8:331-351. https://doi.org/10.1146/ annurev-food-030216-030034.

Ramel, P. R., and A. G. Marangoni. 2018a. Engineering the rheological and thermomechanical properties of model imitation cheese using particle fillers. J. Food Eng. 235:9-15. https://doi.org/10 .1016/j.jfoodeng.2018.03.023.

Ramel, P. R., and A. G. Marangoni. 2018b. Processed cheese as a polymer matrix composite: A particle toolkit for the replacement of milk fat with canola oil in processed cheese. Food Res. Int. 107:110-118. https://doi.org/10.1016/j.foodres.2018.02.019.

Rayan, A. A., M. Kalab, and C. A. Ernstrom. 1980. Microstructure and rheology of process cheese. Scanning Microsc. 3:635-643.

Renard, D., L. Lavenant, C. Sanchez, Y. Hemar, and D. Horne. 2002. Heat-induced flocculation of microparticulated whey proteins (MWP); Consequences for mixed gels made of MWP and $\beta$-lactoglobulin. Colloids Surf. B Biointerfaces 24:73-85. https:// doi.org/10.1016/S0927-7765(01)00246-6.

Sanchez, C., and P. Paquin. 1997. Protein and protein-polysaccharide microparticles. Pages 503-528 in Food Proteins and Their Applications. S. Damodaran and A. Paraf, ed. Marcel Dekker, New York, NY.

Schenkel, P., R. Samudrala, and J. Hinrichs. 2013. The effect of adding whey protein particles as inert filler on thermophysical properties of fat-reduced semihard cheese type Gouda. Int. J. Dairy Technol. 66:220-230. https://doi.org/10.1111/1471-0307.12036.

Silva, D. F., S. B. S. Ferreira, M. L. Bruschi, M. Britten, and P. T. Matumoto-Pintro. 2016. Effect of commercial konjac glucomannan and konjac flours on textural, rheological and microstructural properties of low fat processed cheese. Food Hydrocoll. 60:308-316. https://doi.org/10.1016/j.foodhyd.2016.03.034.

Silva, R. C. S. N., V. P. R. Minim, M. C. R. T. Vidigal, A. N. Silva, A. A. Simiqueli, and L. A. Minim. 2012. Sensory and instrumental consistency of processed cheeses. J. Food Res. 1:204-213. https:// doi.org/10.5539/jfr.v1n3p204.

Singer, N. S. 1996. Microparticulated proteins as fat mimetics. Pages 171-185 in Handbook of Fat Replacers. S. Roller and S. A. Jones, ed. CRC Press, Boca Raton, FL.

Sołowiej, B., I. W. Y. Cheung, and E. C. Y. Li-Chan. 2014. Texture, rheology and meltability of processed cheese analogues prepared using rennet or acid casein with or without added whey proteins. Int. Dairy J. 37:87-94. https://doi.org/10.1016/j.idairyj.2014.03 .003 . 
Sołowiej, B., P. Glibowski, S. Muszyński, J. Wydrych, A. Gawron, and T. Jeliński. 2015. The effect of fat replacement by inulin on the physicochemical properties and microstructure of acid casein processed cheese analogues with added whey protein polymers. Food Hydrocoll. 44:1-11. https://doi.org/10.1016/j.foodhyd.2014 .08 .022 .

Srisuvor, N., N. Chinprahast, C. Prakitchaiwattana, and S. Subhimaros. 2013. Effects of inulin and polydextrose on physicochemical and sensory properties of low-fat set yoghurt with probiotic-cultured banana purée. Lebensm. Wiss. Technol. 51:30-36. https:// doi.org/10.1016/j.lwt.2012.10.018.

Stowell, J. D. 2009. Polydextrose. Pages 173-201 in Fiber Ingredients: Food Applications and Health Benefits. S. S. Cho and P. Samuel, ed. CRC Press, Boca Raton, FL.

Sun, C., T. Wu, R. Liu, B. Liang, Z. Tian, E. Zhang, and M. Zhang. 2015. Effects of superfine grinding and microparticulation on the surface hydrophobicity of whey protein concentrate and its relation to emulsions stability. Food Hydrocoll. 51:512-518. https:// doi.org/10.1016/j.foodhyd.2015.05.027.

Sutheerawattananonda, M., and E. D. Bastian. 1998. Monitoring process cheese meltability using dynamic stress rheometry. J. Texture Stud. 29:169-183. https://doi.org/10.1111/j.1745-4603.1998 .tb00162.x.

Swenson, B. J., W. L. Wendorff, and R. C. Lindsay. 2000. Effects of ingredients on the functionality of fat-free process cheese spreads. J. Food Sci. 65:822-825. https://doi.org/10.1111/j.1365-2621.2000 .tb13594.x.

Szczesniak, A. S. 1963. Classification of textural characteristics. J. Food Sci. 28:385-389. https://doi.org/10.1111/j.1365-2621.1963 .tb00215.x.
Tamime, A. Y., D. D. Muir, M. E. Shenana, M. Kalab, and A. H. Dawood. 1999. Processed cheese analogues incorporating fat-substitutes: 2. Rheology, sensory perception of texture and microstructure. Lebensm. Wiss. Technol. 32:50-59. https://doi.org/10.1006/ fstl.1998.0510.

Thomas, M. A., G. Newell, and G. Abad. 1980. Effects of freezing on the objective and subjective properties of processed cheese. Int. J. Food Sci. Technol. 15:599-605. https://doi.org/10.1111/j.1365 -2621.1980.tb00979.x.

Trivedi, D., R. J. Bennett, Y. Hemar, D. C. W. Reid, S. K. Lee, and D. Illingworth. 2008. Effect of different starches on rheological and microstructural properties of (II) commercial processed cheese. Int. J. Food Sci. Technol. 43:2197-2203. https://doi.org/10.1111/j .1365-2621.2008.01850.x.

Wadhwani, R., and D. J. McMahon. 2012. Color of low-fat cheese influences flavor perception and consumer liking. J. Dairy Sci. 95:2336-2346. https://doi.org/10.3168/jds.2011-5142.

WHO. 2016. Report of the Commission on Ending Childhood Obesity. World Health Organization, Geneva, Switzerland.

\section{ORCIDS}

Christopher N. Schädle @ https://orcid.org/0000-0002-4078-6760 Stephanie Bader-Mittermaier (1) https://orcid.org/0000-0002-4251 $-016 \mathrm{X}$ 